\title{
Penerapan Differentiated Instruction dalam Meningkatkan Pemahaman Konsep Matematika Siswa Kelas 2 SD
}

\author{
Sion Stepani Simanjuntak,Tanti Listiani \\ sionstevanny03@gmail.com, tanti.listiani@uph.edu \\ FIP Universitas Pelita Harapan

\begin{abstract}
The Implementation of Differentiated Instruction in Mathematics Lesson to Improve The Concept Understanding of Grade 2 Primary Students
\end{abstract}

\begin{abstract}
Understanding concepts is one of the important things in learning Mathematics. However, in reality it was found that Grade 2 students had difficulty in understanding the concept of Mathematics. Therefore, in this study a strategy has chosen, namely Differentiated Instruction. The purpose of this study is to determine whether the application of Differentiated Instruction learning strategy can improve the understanding of the concept of class $2 B$ students on Mathematics. The method carried out is the Classroom Action Research (CAR) by Robert Pelton with two cycles. The research was conducted at a Christian school in the West Jakarta area on September 26 to October 16, 2018, conducted with a total of 7 meetings. The instruments to collect data are lesson plans, mentor feedback, reflection journals, tests and documentation (photos). The results of the study shows that the Differentiated Instruction strategy can improve students' understanding of concepts on the three indicators used in this research. The maximum achievement of each indicator is restating a concept (72\%), classifying objects based on certain characteristics according to the concept (100\%), and presenting concepts in various forms of representation (80\%). Differentiated Instruction can improve the understanding concept of, if each of the strategic steps are implemented properly. However, there are some things that need to be considered such as the emphasis on the concept of clear material, giving clear but simple instructions (for lower grade students), giving clear and firm rules, as well as variations in learning according to interests, learning styles, and student readiness.
\end{abstract}

Keywords: Differentiated Instruction, Understanding of Mathematical Concepts

Received date: 23 Agustus 2019

Article Info

Revised date: 4 April 2020
Accepted date: 12 Mei 2020

\section{PENDAHULUAN}

Matematika adalah salah satu mata pelajaran yang wajib dipelajari oleh siswa dari jenjang pendidikan sekolah dasar hingga sekolah menengah atas (Amir A, 2014). Permendiknas RI No.58 tahun 2016 menuliskan bahwa betapa pentingnya peserta didik untuk diberikan pelajaran Matematika sejak dini. Pembelajaran matematika membantu siswa untuk meningkatkan dan memperlengkapi siswa dengan kemampuan berpikir kritis, analitis dan juga sistematis. Ada pun beberapa tujuan pembelajaran Matematika yang dituliskan berdasarkan salah satu Standar Isi Mata Pelajaran Matematika (Wardhani, 2008) untuk semua jenjang pendidikan dasar dan menengah di mana dinyatakan bahwa tujuan mata pelajaran matematika adalah siswa diharapkan mampu memahami konsep matematika, menjelaskan keterkaitan antarkonsep dan mengaplikasikan konsep atau algoritma, luwes, akurat, efisien, dan tepat dalam pemecahan masalah. Oleh karena itu, kemampuan memahami suatu konsep merupakan hal yang sangat mendasar dalam pembelajaran Matematika. Annajmi (2016) juga mengatakan bahwa untuk mengerjakan Matematika diperlukan pemahaman konsep Matematika.

Rosyada (2004) menyatakan bahwa pemahaman (Comprehension) merupakan kemampuan untuk mengerti apa yang sedang dikomunikasikan dan mampu mengimplemetasikan ide tanpa harus melihat ide itu secara mendalam. Pemahaman bukan hanya mengenai seberapa banyak fakta yang diingat, namun berkenaan dengan kemampuan untuk menjelaskan, menerangkan, menafsirkan (interpret), atau kemampuan menangkap makna atau arti suatu konsep. Oleh karena itu, seseorang dapat dianggap memahami suatu konsep jika mereka telah dapat menyatakan ulang apa yang telah 
dipelajarinya termasuk dalam menafsirkan suatu gambar, grafik, ataupun kalimat dengan menggunakan kata-kata mereka sendiri tanpa terpaku dengan hafalan informasi yang diperolehnya namun tetap sesuai dengan konsepnya.

Berdasarkan hasil pengamatan di kelas 2B salah satu sekolah SD kota Jakarta Barat, ditemukan bahwa siswa kesulitan dalam memahami konsep Matematika, hal ini terlihat dari cara siswa mengerjakan soal. Siswa kesulitan dalam menafsirkan soal, baik dalam bentuk kalimat ataupun dalam bentuk gambar. Hal ini berakibat pada rendahnya hasil belajar Matematika siswa. Hasil tes formatif pembelajaran sebelumnya terlihat bahwa dari 26 siswa, hanya terdapat 8 siswa yang memenuhi standar ketuntasan minimal 65 yang dibuat oleh sekolah. Terdapat 17 siswa memiliki nilai kurang dari 65 dan 1 siswa tidak masuk sekolah. Oleh karena itu, pada penelitian ini diputuskan hanya 25 siswa yang dijadikan objek penelitian.

Berdasarkan hasil tes yang diberikan, dapat diambil kesimpulan bahwa siswa kesulitan dalam memahami konsep pembelajaran Matematika, hal ini terlihat dari cara siswa mengerjakan soal. Siswa kesulitan dalam menafsirkan soal, baik dalam bentuk kalimat ataupun dalam bentuk gambar. Hal ini menyebabkan banyak dari jawaban mereka yang tertukar penafsiran (misconcept). Contohnya, saat diminta untuk mengerjakan pengurangan, siswa memilih untuk menjawab dengan cara penjumlahan, ataupun sebaliknya. Padahal, jelas guru sudah menuliskan kata kunci pada soal tersebut seperti add more, put, adding on untuk soal penjumlahan, dan take away, lost pada soal pengurangan. Fenomena lainnya adalah siswa kurang memperhatikan instruksi matematika yang diberikan oleh guru, sehingga sering kali bertanya apa yang harus dilakukan, meskipun instruksi sudah jelas tertulis dan sudah dijelaskan secara verbal. Hal ini juga menyebabkan siswa tidak teliti saat pengerjaan soal. Pada saat penjelasan materi, siswa juga terlihat malu bertanya tentang apa yang belum mereka mengerti, sehingga seringkali guru harus mendatangi siswa satu persatu dan menjelaskan kembali konsep-konsep yang sesuai. Beberapa siswa belum dapat mengerjakan soal secara abstrak ataupun dengan pictorial (gambar), siswa masih membutuhkan (manipulatives) alat bantu seperti based-ten blocks, permen dan piring, untuk membantu siswa dalam menghitung operasi bilangan pada soal.

Rendahnya pemahaman konsep siswa tentu tidak hanya disebabkan oleh siswa. Berdasarkan observasi mentor mengungkapkan bahwa guru pada penelitian ini juga seringkali menjelaskan materi dengan tempo berbicara yang cepat, sehingga menyebabkan siswa dengan tingkat pemahaman rendah kurang dapat menangkap materi dengan baik. Selain itu, mahasiswa guru juga belum menyediakan manipulatives atau alat pembelajaran untuk membantu siswa dengan tingkat pemahaman rendah memahami materi pembelajaran dengan baik.

Berdasarkan pemaparan di atas, pada penelitian ini diputuskan untuk menerapkan Differentiated Instruction untuk meningkatkan pemahaman konsep siswa. Prinsip dari pemberian instruksi atau kegiatan yang berdiferensiasi adalah strategi yang digunakan umtuk mengakui nilai yang ada di setiap individu. Hal ini memungkinkan siswa dari semua latar belakang dan dengan beragam kemampuan untuk menunjukkan apa yang mereka ketahui, pahami, dan mampu mereka lakukan (Adami, 2014). Hal ini juga sejalan dengan penelitian yang dilakukan Joseph (2013) bahwa Differentiated Instruction merupakan strategi yang digunakan untuk meningkatkan dan mengakomodasi kebutuhan pembelajaran siswa baik dari segi kesiapan (kognitif), minat, dan juga profil belajar. Serupa dengan hal tersebut, Ditasona (2017) dalam penelitiannya menunjukkan bahwa penerapan Differentiated Instruction dapat meningkatkan penalaran matematis siswa.

\section{KAJIAN PUSTAKA}

\section{Differentiated Instruction}

Secara umum Differentiated Instruction (DI) adalah strategi pembelajaran dengan menyesuaikan instruksi kepada kebutuhan siswa dengan tujuan memaksimalkan potensi masing-masing peserta didik dalam lingkup yang diberikan (Tomlinson, 2017). Differentiated Instruction didefinisikan sebagai sebuah pembelajaran yang dirancang untuk memenuhi dan membantu keberagaman siswa dalam satu kelas dalam hal kesiapan, ketertarikan, dan profil belajar di mana siswa disediakan pembelajaran yang bervariasi dalam hal konten, proses dan produk (hasil), yang memungkinkan suatu pembelajaran berjalan dengan efektif. Lebih lanjut, Chapman dan King (2012) menyatakan bahwa Differentiated Instruction merupakan pembelajaran yang terdiferensiasi yang dilandaskan pada keberagaman kesiapan (readiness), ketertarikan (interest), dan profil belajar siswa (learning profile). 
Differentiated Instruction juga digambarkan sebagai suatu strategi yang berbasis pada guru dan berpusat pada siswa, di mana guru memegang peran penting dalam merancangkan pembelajaran yang dapat disesuaikan dengan karakteristik siswa.

Sebagian besar topik atau konsep pembelajaran dapat didekati dengan sejumlah cara yang sesuai dengan kebutuhan dan kesiapan siswa. Sehingga, siswa diharapkan melalui pembelajaran terdiferenisasi dan bervariasi ini dapat mengoptimalkan kemampuan mereka dalam memahami suatu konsep matematika dan juga siswa dapat menemukan bahwa pembelajaran matematika merupakan pelajaran yang menarik dan menantang. Gardner (dalam Rose and Nicholl, 2009) mengemukakan bahwa otak manusia memiliki 8 kecerdasan, dan tidak semua kecerdasan tersebut dapat digunakan oleh manusia dalam memahami suatu konsep. Tujuh kecerdasan berbeda yang dimiliki manusia menghasilkan suatu gaya belajar dan komunikasi yang berbeda. Hal ini juga selaras dengan penelitian yang dilakukan Fischer dan Rose (2001), yang ditemukan bahwa setiap individu tidak belajar dengan cara yang sama. Gaya belajar dan cara siswa menerima pembelajaran merupakan salah satu faktor yang membuat siswa dapat memahami konsep pembelajaran itu sendiri, dalam hal ini matematika.

Langkah-langkah penerapan Differentiated Instruction yang digunakan pada penelitian ini yaitu mengacu pada teori menurut Tomlinson dan Eidson (2003) yaitu dengan mendiagnosa kesiapan belajar (melakukan pre-test), mengklarifikasi materi, dan mendesain pengalaman belajar yang bervariasi (variasi konten latihan soal, variasi minat, dan variasi profil belajar).

\section{Pemahaman Konsep}

Pemahaman konsep diartikan sebagai suatu kemampuan berpikir dalam menyerap makna akan suatu hal agar mampu menyatakan ulang atau menggambarkan makna tersebut kembali ke dalam bahasa yang mudah untuk dipahami. Annajmi (2016) juga berpendapat bahwa seorang siswa memiliki pemahaman konsep yang baik jika mampu menjelaskan konsep kembali, mampu memberikan mana yang contoh dan bukan contoh dari konsep serta menggunakan konsep tersebut dalam memecahkan suatu masalah. Sementara menurut John Tetiwar dan Oce Appulembang (2018), pemahaman konsep adalah kemampuan dasar dalam mengartikan suatu konsep yaitu jika dapat menjelaskan ulang konsep yang telah diterima dengan menggunakan kalimat yang dapat dimengerti serta dapat memecahkan masalah berkaitan dengan konsep tersebut dan mengaitkan dengan konsep yang lainnya. Ningsih, Y Sri (2017) juga mengatakan bahwa dalam proses pembelajaran matematika, kemampuan pemahaman konsep sangat penting, karena kemampuan pemahaman konsep siswa pada topik tertentu dipengaruhi oleh pemahaman konsep siswa pada topik sebelumnya.

Pemahaman konsep merupakan suatu aspek penting dalam pembelajaran, jika seorang siswa sudah mencapai pemahaman yang mendalam dan bermakna tentang sebuah konsep maka siswa tersebut dapat mengembangkan kemampuannya baik dalam materi pelajaran maupun kehidupan sehari-hari. Tung (2015, hal. 219) juga menjelaskan bahwa keberadaan pemahaman konsep dapat membantu seseorang dalam hal "meringkas, menyederhanakan, dan mengorganisasi informasi yang ada". Dengan demikian, pemahaman konsep terhadap pembelajaran matematika merupakan hal yang penting, karena hal tersebut merupakan suatu dasar yang akan menuntun siswa untuk memahami suatu topik atau materi pembelajaran yang diharapkan dapat membantu mengembangkan kemampuan matematika siswa dalam hal meringkas, menyederhanakan ataupun mengorganisasi suatu informasi pada jenjang topik selanjutnya dan juga dapat membuat pembelajaran matematika lebih bermakna.Menurut pendapat Febriyanto, Budi dkk (2018), pemahaman konsep matematis sangat penting, karena dengan penguasaan konsep matematis akan mempermudah siswa dalam mempelajari matematika dan menerapkannya dalam kehidupan sehari-hari.

Indikator pemahaman konsep matematika menurut Sanjaya (2009) yaitu menyatakan ulang sebuah konsep, mengklasifikasi objek berdasarkan sifat-sifat tertentu (sesuai dengan konsepnya), memberikan contoh dan non-contoh dari konsep, memberikan konsep dalam berbagai representasi matematis, menerapkan konsep atau alogaritma matematis. Sementara menurut Killpatrick, Swafford \& Findell (dalam Afrilianto, 2012, hal. 196), indikator pemahaman konsep matematika, yaitu sebagai berikut menyatakan ulang secara verbal konsep yang telah dipelajari, mengklasifikasi objek-objek berdasarkan dipenuhi atau tidaknya persyaratan untuk membentuk konsep tersebut, menerapkan konsep secara alogaritma, menyajikan konsep dalam berbagai macam bentuk representasi matematika, mengaitkan berbagai konsep (internal dan eksternal matematika). Indikator yang digunakan pada penelitian ini menyesuaikan pada jenjang usia dan materi yang diberikan yaitu materi perkalian dan 
pembagian (multiplication and division). Indikator tersebut adalah; 1) Menyatakan ulang sebuah konsep; 2) Mengklasifikasi objek berdasarkan sifat-sifat tertentu (sesuai dengan konsepnya); 3) Menyajikan konsep dalam berbagai bentuk representasi.

\section{METODE PENELITIAN}

Metode penelitian yang digunakan adalah penelitian tindakan kelas (PTK). Menurut Pelton (2010) penelitian tindakan kelas dibagi berdasarkan dua kata dasar yaitu tindakan (action) dan penelitian (research). Tindakan merupakan hampir semua hal yang dilakukan dalam rutinitas pengajaran sehari-hari. Pada konteks ini, penelitian tindakan kelas dilakukan dengan cara memerhatikan prosedur penelitian dan juga memahami permasalahan yang terjadi di dalam kelas sambil melakukan perubahan dan perbaikan. Metode penelitian tindakan kelas memiliki lima tahapan yaitu, identifikasi masalah (Issue Identification), penyajian data (Data Collection), perencanaan pelaksanaan (Action Planning), pelaksanaan tindakan (Plan Activation), asesmen luaran (Outcome Assessment) (Pelton, 2010, hal. 9). Subjek Penelitan ini adalah 25 siswa kelas 2B salah satu sekolah di daerah Jakarta Barat. Penelitian dilaksanakan pada tanggal 26 September - 16 Oktober 2018.

Instrumen yang digunakan untuk mengukur keberhasilan strategi Differentiated Instruction adalah jurnal refleksi dan umpan balik mentor. Instrumen yang digunakan untuk melihat keberhasilan pemahaman konsep adalah jurnal refleksi, umpan balik mentor dan hasil tes.

\section{HASIL PENELITIAN DAN PEMBAHASAN}

Strategi Differentiated Instruction yang diterapkan pada penelitian ini terbukti dapat meningkatkan pemahaman konsep siswa. Peningkatan dan penurunan hasil indikator tentu terjadi pada proses pembelajaran. Presentase ketuntasan belajar siswa juga terlihat meningkat setiap penerapan tindakan. Seperti yang dapat dilihat dari diagram berikut.

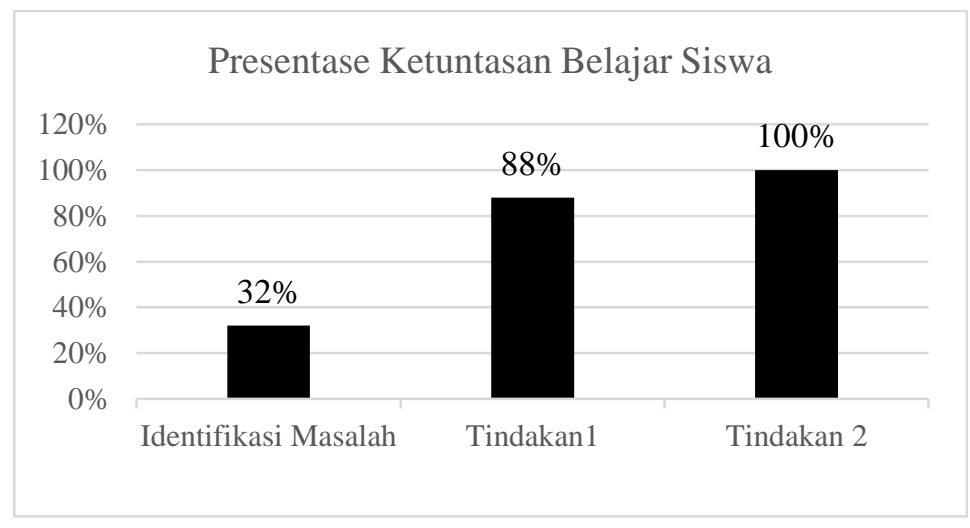

Diagram 1 Presentase Ketuntasan Belajar Siswa

Dari data di atas dapat dilihat bahwa sebelum penerapan tindakan hanya terdapat 8 siswa yang lulus tes. Setelah dilakukan tindakan pertama hasil tes siswa meningkat sebanyak 56\%, sehingga sebanyak 22 siswa lulus tes materi perkalian. Untuk meyakinkan kembali keberhasilan tindakan strategi, maka pada materi selanjutnya yaitu pembagian (division) penerapan strategi dilakukan kembali. Setelah dilihat kembali, hasil tes siswa meningkat sebanyak 12\%, sehingga seluruh kelas (25 siswa) dapat lulus di tes materi pembagian. Hasil ini sejalan dengan penelitian yang sudah pernah dilakukan oleh Borja, Laura dkk (2015), yang mengatakan bahwa Differentiated Instruction dapat membantu kemajuan siswa untuk mencapai tujuan pembelajaran di kelas. Melalui Differentiated Instruction, guru dapat mengenal siswa secara individu dan membantu siswa untuk mengetahui apa saja yang menjadi kebutuhan siswanya serta membuat siswa lebih tertarik dan belajar dengan lebih bermakna. 


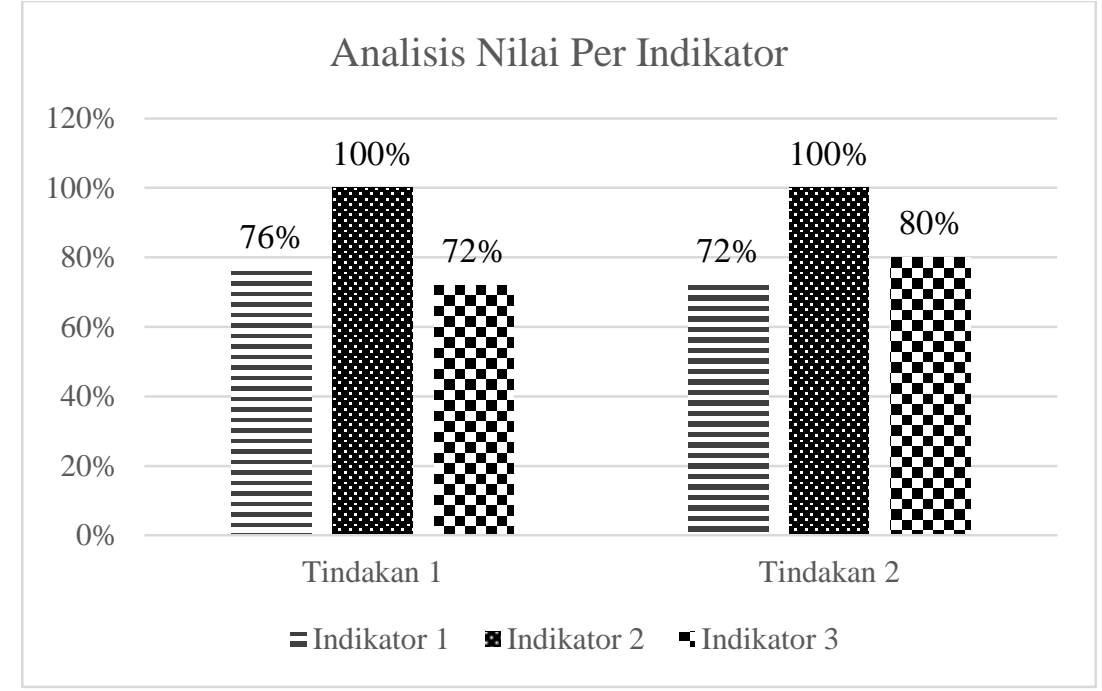

Diagram 2 Analisis Nilai Per Indikator

Hasil persentasi nilai tes menunjukkan terjadi penurunan pada indikator satu pada tindakan pertama ke tindakan kedua sebanyak $4 \%$. Hal ini disebabkan karena salah satu siswa tidak mengerjakan soal pada indikator tersebut dikarenakan siswa kehabisan waktu. Namun, pada soal yang lain siswa tersebut mengerjakan dengan baik sehingga pada indikator lain siswa mencapai skor maksimal. Pada indikator 2 seluruh siswa dapat menjawab soal dengan benar, baik pada tindakan pertama maupun pada tindakan kedua. Pada indikator 3, tindakan pertama juga mengalami peningkatan sebanyak $8 \%$. Pada penelitian ini dianalisis bahwa peningkatan terjadi karena sebelumnya pada tindakan pertama, station yang dilaksanakan pada siswa tidak lengkap akibat keterbatasan waktu. Kemudian, pada penelitian ini di refleksikan dan diatur kembali penempatan waktu yang efektif serta suasana yang kondusif sehingga setiap station yang telah disusun dapat diikuti siswa secara lengkap. Selain itu, pada langkah klarifikasi konsep materi serta diferensiasi siswa juga dilakukan lebih maksimal saat di tindakan kedua. Hal ini juga didukung oleh kondisi siswa yang sudah mulai menyesuaikan dan mengerti setiap instruksi dari penerapan strategi pada tindakan pertama. Berdasarkan hasil tersebut, dapat dikatakan bahwa Differentiated Instruction dapat meningkatkan pemahaman konsep siswa. Dari penerapan pertama dan kedua menunjukkan adanya kekonsistenan bahwa penggunaan Differentiated Instruction dapat meningkatkan pemahaman konsep siswa. Maka dari itu, sebagai pengajar seorang guru di sarankan untuk dapat menggunakan strategi Differentiated Instruction, karena dapat membantu pemahaman siswa meski kemampuan matematika siswa sangat bervariasi. Differentiated Instruction membantu guru untuk dapat memahami setiap siswa yang diajarnya dengan lebih baik, sehingga guru mampu mengerti apa yang menjadi kebutuhan masing-masing siswanya dan memberikan penanganan tersendiri dengan siswa-siswa yang diajar. Hal ini sejalan dengan penelitian yang pernah dilakukan oleh Bajrami, Iranda (2013), bahwa Differentiated Instruction dapat membantu guru untuk melihat kemampuan siswa-siwanya dengan bervariasi serta dapat memberikan desain pembelajaran yang berbeda-beda untuk siswanya berdasarkan tingkatan kemampuannya.

Berdasarkan penelitian ini, ada empat hasil temuan yang ditemukan saat penerapan Differentiated Instruction. Pertama adalah bahwa Differentiated Instruction dapat meningkatkan pemahaman konsep matematika siswa kelas 2 SD. Hal ini terbukti dari hasil tes yang meningkat setiap tindakan. Kedua, pada penelitian ini ditemukan bahwa adanya kemungkinan kelas yang menjadi lebih gaduh. Oleh karena itu, pada tindakan kedua dijelaskan bahwa perlunya penjelasan instruksi dan peraturan yang tegas, jelas dan konsisten. Untuk mengurangi kegaduhan kelas, guru menggunakan voice level chart serta instrumen lagu yang berfungsi sebagai batasan kebisingan suara saat berdiskusi di dalam kelompok. Ketiga, pada penelitian ini disadari bahwa banyaknya lembar kerja yang harus dikoreksi oleh guru. Oleh karena itu, pada tindakan kedua juga telah diterapkan sistem peer-checking pada salah satu station (Logic station). Siswa diharapkan untuk dapat menganalisis kembali lembar jawaban rekan sejawatnya dengan mengoreksi jawaban teman dalam satu kelompoknya. Namun, guru juga harus tetap memonitor kinerja setiap siswa Keempat, pada penelitian ini juga ditemukan bahwa Differentiated Instruction dapat meningkatkan kemampuan kooperatif siswa. Hal ini disebabkan karena 
prinsip pengelompokkan yang flexible dan heterogen (individual - pair - home based group) yang ada pada strategi ini membuat siswa memaksimalkan kinerjanya. Flexible Grouping adalah istilah yang mencakup berbagai jenis pengelompokkan siswa untuk menyampaikan instruksi, seperti seluruh kelas, kelompok kecil, partner ataupun individu (Tomlinson, 2001). Siswa dikelompokkan dan dikelompokkan kembali (regroup) sesuai dengan tujuan, kegiatan, dan kebutuhan individu tertentu. Sebagai contoh, pada pelaksanaan langkah kedua (clarifying material) saat siswa mengerjakan latihan soal, mereka dibagi menjadi dua kelompok. Siswa yang belum memahami konsep atau masih memerlukan manipulatives akan berada di dalam satu kelompok kecil yang di mana guru akan berada di sana untuk memberikan penjelasan kembali konsep atau keterampilan dengan cara yang berbeda, atau dengan memberikan latihan tambahan. Sedangkan, untuk kelompok lain telah disediakan latihan soal ataupun soal tambahan dengan kesulitan yang berbeda. Hal seperti ini, dapat membantu mengejar ketertinggalan siswa yang memiliki pemahaman yang kurang, dan mengurangi adanya kesenjangan antara low level learner dengan high level learner.

\section{SIMPULAN DAN SARAN}

\section{Simpulan}

Berdasarkan Penelitian Tindakan Kelas yang dilakukan pada kelas 2 SD di suatu sekolah Kristen daerah Jakarta Barat dapat disimpulkan bahwa; 1) Penerapan strategi Differentiated Instruction pada mata pelajaran Matematika di kelas 2 dapat meningkatkan pemahaman konsep Matematika siswa, 2) Strategi Differentiated Instruction dapat meningkatkan pemahaman konsep siswa, jika setiap langkah-langkah strategi diterapkan. Beberapa hal yang juga perlu diperhatikan seperti penekanan pada konsep materi yang jelas, pemberian instruksi yang jelas namun sederhana (untuk siswa lower grade), pemberian peraturan yang jelas dan tegas, serta variasi pembelajaran yang sesua dengan minat, gaya belajar, serta kesiapan siswa. Berdasarkan penelitian ini disadari bahwa setiap siswa memiliki kemampuan berpikir dengan cara yang berbeda dan sesuai dengan kapasitas yang Allah telah berikan. Van Brummelen (2006, hal.22) menuliskan bahwa konsep dan keterampilan merupakan suatu alat untuk mencapai hasil akhir, bukan sebagai hasil akhir itu sendiri. Hal ini berarti, kemampuan memahami konsep matematika bukanlah tujuan akhir siswa dalam pembelajaran. Melalui kemampuan memahami konsep matematika, siswa diharapkan memiliki pertumbuhan pengenalan akan Allah yang sejati dan berdaulat atas segala hukum-hukum, susunan, dan ciptaan di muka bumi. Pada pelaksanaan penelitian ini juga diharapkan siswa dan guru mampu menyadari bahwa pemahaman suatu konsep merupakan suatu bentuk kebergantungan manusia terhadap hikmat yang bersumber dari Allah.

\section{Saran}

Beberapa hal yang juga perlu diperhatikan seperti penekanan pada konsep materi yang jelas, pemberian instruksi yang jelas namun sederhana (untuk siswa lower grade), pemberian peraturan yang jelas dan tegas, serta variasi pembelajaran yang sesuai dengan minat, gaya belajar, serta kesiapan siswa. Saat pelaksanaan strategi Differentiated Instruction dapat sekaligus diputarkan musik saat kegiatan atau voice level chart untuk membantu mengontrol keramaian kelas saat melaksanakan station. Instruksi, peraturan, dan pergerakan station merupakan hal yang sering kali siswa lupakan. Penting untuk guru selalu ingatkan dan tuliskan dengan jelas di papan tulis ekspetasi atau peraturan-peraturan yang penting untuk dilaksanakan saat kegiatan berlangsung. Alokasi waktu merupakan suatu hal yang sangat penting. Pastikan tingkat kesulitan soal dapat ditangani sesuai dengan alokasi waktu yang tersedia. Tidak perlu terburu-buru, jika tidak selesai pertemuan selanjutnya dapat digunakan dalam pengimplementasian strategi ini. Alat dan bahan sangat diperlukan untuk membantu siswa low level learner dalam membangun pemahaman konsep mereka terhadap matematika. Terutama untuk kelas kecil, siswa kelas 2 seperti pada penelitian ini sebagian sangat membutuhkan manipulatives yang dapat menjadi dasar pemahaman konsep mereka sebelum berangkat ke jenjang abstrak (mengartikan ke dalam bentuk operasi bilangan).

Saran sebagai penelitian selanjutnya adalah peneliti bisa memadukan strategi Differentiated Instruction ini dengan model atau media pembelajaran lain, selain itu peneliti perlu melakukan tes yang lebih mendalam untuk dapat mengetahui secara lebih jelas mengenai jenis tingkatan kemampuan siswa yang akan diajar. 
Penerapan Differentiated Instruction dalam Meningkatkan Pemahaman Konsep Matematika Siswa

Kelas 2 SD (Sion Stepani Simanjuntak,Tanti Listiani)

\section{DAFTAR PUSTAKA}

Adami, A.F. 2014. Enhancing Students' Learning Through Differentiated Approaches to Teaching and Learning: A Maltese Perspective. Journal of Research in Special Educational Needs, 4(2), 9197.

Afrilianto,M. 2012. Peningkatan Pemahaman Konsep dan Kompetensi Strategis Matematis Siswa SMP dengan Pendekatan Metaphorical Thinking. Jurnal Ilmiah Program Studi Matematika STKIP Siliwangi Bandung,1(2).

Amir, Almira. 2014. Pembelajaran Matematika SD dengan Menggunakan Media Manipulatif. Forum Paedagogik, 6(1).

Annajmi. 2016. Peningkatan Kemampuan Pemahaman Konsep Matematik Siswa SMP Melalui Metode Penemuan Terbimbing Berbantuan Software Geogebra. Journal of Mathematics Education and Science, 2(1), 2.

Bajrami, Iranda. 2013. The Importance of Differentiation in Supporting Diverse Learners. Journal of Education and Practice, 4(22).

Borja, Laura dkk. 2015. Differentiating Instruction for EFL Learners. International Journal of Humanities and Social Science, 5(8), 1.

Chapman, C., \& King, R. 2012. Differentiated Assessment Strategies: One Tool doesn't Fit All. Thousand Oaks, CA: Corwin Press.

Ditasona, C. 2017. Pengaruh Penerapan Pendekatan Kontekstual Terhadap Peningkatan Kemampuan Pemecahan Masalah Matematis Siswa. AKSIOMA: Jurnal Penerapan Pendekatan Differentiated Instruction dalam Peningkatan Kemampuan Penalaran Matematis Siswa SMA Program Studi Pendidikan Matematika, 2(1), 43-54.

Febriyanto, Budi dkk. 2018. Peningkatan Pemahaman Konsep Matematis Melalui Penggunaan Media Kantong Bergambar pada Materi Perkalian Bilangan di Kelas II Sekolah Dasar. Jurnal Cakrawala Pendas, 4(2).

Joseph, S., Thomas, M., Simonette, G., \& Ramsook, L. 2013. The Impact of Differentiated Instruction in a Teacher Education Setting: Successes and Challenges. International Journal of Higher Education, 2(3).

Ningsih, Y Sri. 2017. Peningkatan Kemampuan Pemahaman Konsep Siswa Melalui Pendekatan Matematika Realistik di SMP Swasta Tarbiyah Islamiyah. MES (Journal of Mathematics Education and Science), 3(1).

Pelton, R. P. 2010. Action Research for Teacher Candidates: Using Classroom Data to Enhance Instruction. Lanham, MD: Rowman \& Littlefield Education.

Rose, C dan Nicholl Malcolm J. 2009. Accelerated Learning for the 21st Century.

Rosyada, D. 2004. Paradigma Pendidikan Demokratis. Jakarta: Kencana.

Sanjaya, W. 2009. Strategi Pembelajaran Berorientasi Standar Proses Pendidikan. Jakarta: Kencana Prenada Media Group.

Tetiwar, J dan Appulembang,. 2018. Penerapan Metode Peer Tutoring untuk Meningkatkan Pemahaman Konsep Materi Perkalian Bersusun pada Siswa Kelas III SD. Scholaria: Jurnal Pendidikan dan Kebudayaan, 8(3), 302-308.

https://ejournal.uksw.edu/scholaria/article/view/1818/971

Tomlinson, C. A. 2017. Differentiated Instruction. Fundamentals of Gifted Education, 279-292.

Tomlinson, C. A. 2001. How to Differentiate Instruction in Mixed-Ability Classrooms. Upper Saddle River, NJ: Pearson/Merrill Prentice Hall.

Tung, K. Y. 2015. Pembelajaran dan Perkembangan Belajar. Jakarta Barat: PT INDEKS. 
Scholaria: Jurnal Pendidikan dan Kebudayaan, Vol. 10 No. 2, Mei 2020: 134-141

Van Brummelen, H. 2006. Berjalan dengan Tuhan di dalam kelas: Pendekatan Kristiani untuk Pembelajaran. Jakarta: Universitas Pelita Harapan Press.

Wardhani, S. 2008. Analisis SI dan SKL Mata Pelajaran Matematika SMP/MTs untuk Optimalisasi Tujuan Mata Pelajaran Matematika. Yogyakarta: Pusat Pengembangan dan Pemberdayaan Pendidik dan Tenaga Kependidikan Matematika. Bandung: Nuansa. 